\title{
Renin Activity Measurement
}

National Cancer Institute

\section{Source}

National Cancer Institute. Renin Activity Measurement. NCI Thesaurus. Code C111305.

The determination of the amount of renin activity present in a sample. 